\section{Fertilization Methods for Organic and Conventional Potted Blueberry Plants}

\author{
Mary Jane Clark \\ School of Environmental \& Horticultural Studies, Niagara College, 135 \\ Taylor Road, S.S. 4, Niagara-on-the-Lake, Ontario, LOS 1J0, Canada \\ Youbin Zheng \\ School of Environmental Sciences, University of Guelph, 50 Stone Road East, \\ Guelph, Ontario, N1G 2W1, Canada
}

Additional index words. coir, leachate, mineral nutrition, nitrogen, Vaccinium corymbosum

\begin{abstract}
This study determined optimal fertilization for each of three production methods (i.e., two organic and one conventional) of potted Vaccinium corymbosum 'Duke' northern highbush blueberry plants. The three production methods were as follows: 1) organic granular $[(\mathrm{OG})$ organic coir substrate fertilized with Bio-Fert General Purpose + bloodmeal applied at 4.4, 7.3, 10.2, 13.1, and 16.0 g/pot nitrogen $(\mathrm{N})], 2)$ organic liquid $[(\mathrm{OL})$ organic coir substrate fertilized with Bio-Fert GeneralPurpose Liquid + calcium oxide $(\mathrm{CaO})$ applied at 12.2, 14.7, 18.6, 25.3, and $39.5 \mathrm{mmol} \cdot \mathrm{L}^{-1}$ $\mathrm{N})$, and 3 ) conventional $(\mathrm{C}$; pine bark, coir, and peat substrate fertilized with Osmocote Plus 15N-3.9P-9.9K, 5- to 6-month-duration controlled-release fertilizer applied at 4.4, 7.3, 10.2, 13.1, and $16.0 \mathrm{~g} / \operatorname{pot} \mathrm{N})$. Blueberry plants were grown in \#5 black, squat nursery containers outdoors in the Niagara peninsula, $O N$, Canada for two (2015-16) growing seasons. Both of the organic and the conventional production systems produced healthy blueberry plants when fertilizer was applied appropriately. With fertilizer application at 4.4 and 7.3 $\mathrm{g} / \mathrm{pot} \mathrm{N}$ for $\mathrm{C}, 12.2$ and $14.7 \mathrm{mmol} \cdot \mathrm{L}^{-1} \mathrm{~N}$ for the $\mathrm{OL}$, and 8.50 to $13.95 \mathrm{~g} / \mathrm{pot} \mathrm{N}$ for the OG treatments, healthy plant growth was observed in combination with low nutrient leaching. High fertilizer rates resulted in excessive root zone electrical conductivity (EC), poor plant growth, and interveinal chlorosis, which affected fruit production negatively. For $\mathrm{C}$ and $\mathrm{OL}$ treatments, fertilization at rates of 4.4, 7.3 and $10.2 \mathrm{~g} / \mathrm{pot} \mathrm{N}$, and $12.2,14.7$, and $18.6 \mathrm{mmol} \cdot \mathrm{L}^{-1} \mathrm{~N}$, respectively, produced the greatest total fresh weight of fruit. For OG, a large total fruit fresh weight was produced by all plants with no difference among fertilizer rates. This study suggests optimal fertilizer rates from 4.4 to 7.3 g/pot $\mathrm{N}$ for $\mathrm{C}, 12.2$ to $14.7 \mathrm{mmol} \cdot \mathrm{L}^{-1} \mathrm{~N}$ for the $\mathrm{OL}$ treatment, and from 8.50 to 13.95 g/pot $\mathrm{N}$ for the $\mathrm{OG}$ treatment can be applied based on the methods described in this study during potted blueberry production in nurseries and home gardens.
\end{abstract}

Blueberry production is currently of great interest as a result of the known health benefits of the fruit. Highbush blueberry hectarage has been increasing steadily, with the 2010 hectarage totaling $9100,46,300$, and 77,300 ha in Canada, North America, and worldwide, respectively (Brazelton, 2011). The increase in planted highbush blueberry hectarage requires healthy nursery stock,

Received for publication 25 July 2019. Accepted for publication 31 Oct. 2019.

Published online 3 February 2020.

This work was financially supported by Agriculture and Agri-Food Canada through the Canadian Ornamental Horticulture Alliance (COHA) to Y.Z. We thank Willowbrook Nurseries, Blue Sky Nursery Ltd., Milleniumsoils Coir (a division of VGROVE Inc.), ICL Specialty Fertilizers, AG Global and Bio-Ag Consultants and Distributors, Inc. for their supply of plants and other experimental materials. We also thank Sarah Hall, Micah Diller Harder, and Hillary MacDougall for their technical assistance.

Y.Z. is the corresponding author. E-mail: yzheng@ uoguelph.ca.

This is an open access article distributed under the CC BY-NC-ND license (https://creativecommons. org/licenses/by-nc-nd/4.0/). plants to organic growing substrates and fertilizers (Miller et al., 2006; Strik et al., 2017). Some successful growing substrates for potted blueberries have included such components as coir, perlite, turf, peat, bark, wood fiber, sphagnum moss, and sand (Heiberg and Lunde, 2006; Hortidaily, 2015; Kingston et al., 2017; Miller et al., 2006; Smolarz, 1985); however, an industrystandard growing substrate for containerized blueberry production has not been identified. An appropriate growing substrate for containerized blueberry production must ensure appropriate physical properties and drainage because of the susceptibility of fine blueberry roots to root rot in poorly drained soils (de Silva et al., 1999). Physical properties for a typical nursery growing substrate include a total porosity of $50 \%$ to $85 \%$ (Agriculture and Agri-Food Canada, 2003), with appropriate levels for potted blueberries at the high end of this range [e.g., $76 \%$ to $86 \%$ (Kingston et al., 2017)]. In addition, appropriate chemical properties of the growing substrate need to be maintained during containerized blueberry production, including $\mathrm{pH}$ (4.2-5.5), EC $\left(<2.0 \mathrm{mS} \cdot \mathrm{cm}^{-1}\right)$, and nutrient concentrations (Kingston et al., 2017; Machado et al., 2014; Puls, 1999; Retamales and Hancock, 2012). Despite the great influence of fertilization strategies on the root-zone environment, limited research has evaluated nutrient management strategies using conventional and organic fertilizers for containerized northern highbush blueberry production (Miller et al., 2006; Smolarz, 1985). Therefore, further research is needed to develop nutrient management strategies for potted blueberry plant production in commercial nurseries and also for home gardeners to grow and maintain healthy, high-yielding potted blueberry plants.

In addition, current nursery production of blueberry plants is most commonly in a \#1 or \#2 nursery container size, using conventional growing substrates and fertilizers. However, to reach additional markets, especially consumers favoring long-term organic container production of blueberries, nursery production practices can be adapted to supply a complimentary product. To ensure low-maintenance solutions for consumers, finishing nurserygrown blueberry plants in a larger container (i.e., \#5 vs. \#1 or \#2), in combination with organic production, will eliminate the inconvenience of repotting for consumers, at least for the first year. This large, organically grown blueberry plant has the potential to be a value-added product for nursery growers. Therefore, this study aimed to develop fertilization methods for organic and conventional \#5 potted northern highbush blueberry plants. Specifically, the objective of this study was to determine the optimal fertilization rates for each of following three methods for \#5 potted Vaccinium corymbosum 'Duke' production: organic substrate with organic granular (OG) fertilizer, organic substrate with organic liquid (OL) fertilizer, and conventional substrate with controlled-release conventional (C) fertilizer. 


\section{Materials and Methods}

Plant material and growing substrates. One-year-old northern highbush blueberry plants (Vaccinium corymbosum L. 'Duke'; Willowbrook Nurseries, Fenwick, ON, Canada) grown in a \#1 nursery container had the roots washed to remove all growing substrate before planting bare root into a \#5 black, squat nursery container (top diameter, 31.5 $\mathrm{cm}$; height, $23.0 \mathrm{~cm}$ ). Immediately before planting on 30 June 2015, growing substrates were moistened with municipal-sourced tap water ( $\mathrm{pH}, 7.78$; EC, $0.2 \mathrm{mS} \cdot \mathrm{cm}^{-1}$; bicarbonate alkalinity, $\left.0.1 \mathrm{mg} \cdot \mathrm{L}^{-1}\right)$. Containers were filled with $14.5 \mathrm{~L}$ of either a conventional or organic growing substrate, adjusted to consistent compactness and depth (i.e., $2 \mathrm{~cm}$ below the container rim). The conventional growing substrate, consisting of composted pine bark, coir, and peat was mixed by GroBark (Ontario) Ltd. (Milton, ON). The organic substrate was $100 \%$ coir supplied by a local company (Milleniumsoils Coir, a division of VGROVE Inc., St. Catharines, ON). At planting, the root-zone $\mathrm{pH}$ and $\mathrm{EC}$ values were 4.8 and $1.05 \mathrm{mS} \cdot \mathrm{cm}^{-1}$ for the conventional, and 5.7 and $2.5 \mathrm{mS} \cdot \mathrm{cm}^{-1}$ for the organic growing substrates, respectively, as analyzed from leachate obtained using the pour-through procedure (Wright, 1986). Before fertilizer application, plant-available nutrient levels in the growing substrate for the conventional and organic substrates, respectively, were as follows: $<0.04$ and $0.43 \mathrm{mmol} \cdot \mathrm{L}^{-1}$ nitrate $\left(\mathrm{NO}_{3}\right),<0.04$ and $<0.04 \mathrm{mmol} \cdot \mathrm{L}^{-1}$ ammonium $\left(\mathrm{NH}_{4}\right), 0.12$ and $4.46 \mathrm{mmol} \cdot \mathrm{L}^{-1}$ phosphorus $(\mathrm{P})$, 3.50 and $10.65 \mathrm{mmol} \cdot \mathrm{L}^{-1}$ potassium $(\mathrm{K}), 1.36$ and $0.15 \mathrm{mmol} \cdot \mathrm{L}^{-1}$ magnesium $(\mathrm{Mg}), 0.88$ and $<0.03 \mathrm{mmol} \cdot \mathrm{L}^{-1}$ calcium $(\mathrm{Ca}), 2.05$ and 0.29 $\mathrm{mmol} \cdot \mathrm{L}^{-1}$ sulfate $\left(\mathrm{SO}_{4}\right), 1.88$ and $5.10 \mathrm{mmol} \cdot \mathrm{L}^{-1}$ sodium $(\mathrm{Na})$, and 3.50 and $15.43 \mathrm{mmol} \cdot \mathrm{L}^{-1}$ chloride $(\mathrm{Cl})$, as analyzed using a saturated paste extraction method (SGS Agri-Food Laboratories, Guelph, ON). The conventional and organic substrates, on average, had $85.2 \%$ and $85.0 \%$ total porosity, $21.6 \%$ and $35.9 \%$ air-filled porosity, $63.6 \%$ and $49.1 \%$ waterholding capacity, and 0.19 and $0.097 \mathrm{~g} \cdot \mathrm{cm}^{-3}$ bulk density, as analyzed using the North
Carolina State University porometer method (Fonteno and Harden, 2014) at the University of Guelph (Guelph, ON).

Three fertilization methods were tested: 1) $\mathrm{C}, 2$ ) OG fertilizer, and 3 ) OL fertilizer. For $\mathrm{C}$, a controlled-release fertilizer [(CRF) Osmocote Plus $15 \mathrm{~N}-3.9 \mathrm{P}-9.9 \mathrm{~K}, 5-$ to 6-month duration) was applied to the growing substrate surface (top-dressed) at one of five fertilizer rates (i.e., 4.4, 7.3, 10.2, 13.1 or 16.0 $\mathrm{g} /$ pot $\mathrm{N}$ ) right after transplanting on 30 June 2015 , and the same rate was reapplied by topdressing on 8 June 2016. For OG, before planting into the organic substrate on 30 June 2015 , one-quarter of the total amount for one of five rates (i.e., 4.4, 7.3, 10.2, 13.1, or 16.0 $\mathrm{g} /$ pot $\mathrm{N}$ ) of fertilizer [1:1.82 general-purpose $4 \mathrm{~N}-1.3 \mathrm{P}-7.5 \mathrm{~K}$ (BioFert Manufacturing Inc., Chilliwack, BC):bloodmeal $12 \mathrm{~N}-0 \mathrm{P}-0 \mathrm{~K}$ (BioFert Manufacturing Inc.)] was incorporated into the growing substrate, with the remainder of the fertilizer top-dressed in two equal applications on 31 July and 21 Aug. 2015. An additional OG top-dressed application at the same rate was done on 8 June 2016. No fertilizer was applied to the OL fertilizer method at planting, but at each watering event thereafter, after a 1-week establishment period, OL plants were fertilized with a 1:13.1 stock solution of general-purpose $2.5 \mathrm{~N}-13.1 \mathrm{P}-4.2 \mathrm{~K}$ liquid fertilizer (BioFert Manufacturing Inc.):0N-0P-0K $+6 \mathrm{CaO}$ (BioFert Manufacturing, Inc.) diluted at tap water:stock solution ratios of 80:1, 66:1, $52: 1,38: 1$, and $24: 1$ to produce one of five rates (i.e., 12.2, 14.7, 18.6, 25.3, and 39.5 $\mathrm{mmol} \cdot \mathrm{L}^{-1} \mathrm{~N}$ ) with target $\mathrm{EC}$ values between 1.0 and $3.5 \mathrm{mS} \cdot \mathrm{cm}^{-1}$.

After transplanting, $\approx 2 \mathrm{~L}$ tap water was added by hand to each container with a hose to settle the growing substrate around the plant roots, and all plants were watered by hand with a hose for the first week after transplanting, as needed, to reduce stress and facilitate establishment. All plants with the same fertilization method were watered when the average growing substrate moisture for the fertilization method was at or less than $20 \%$ volumetric water content (VWC), as measured by a Pro-Check hand- held meter and a GS3 VWC/temperature/ EC sensor (Hoskin Scientific Ltd., Burlington, $\mathrm{ON}$ ). Plants grown with the $\mathrm{C}$ fertilization method were watered with $1.5 \mathrm{~L}$ tap water by hand with a hose fitted with a Gardena electronic water meter (Gardena Canada Ltd., Brampton, ON). Before 28 July 2015, OG plants were watered with 1.5 $\mathrm{L}$ tap water and, after this date, OG plants were watered with tap water adjusted to $\mathrm{pH}$ $5.0 \pm 0.2$ using apple cider vinegar (Bio-Ag Consultants \& Distributors, Inc., Wellesley, $\mathrm{ON})$. Plants grown with the OL fertilization method were watered alternating with either $1.5 \mathrm{~L}$ tap water or $1.5 \mathrm{~L}$ of the appropriate rate of OL fertilizer, measured manually for each container, which was $\mathrm{pH}$-adjusted to $5.0 \pm 0.2$ using apple cider vinegar during the 2015 and 2016 growing seasons.

Growing environment and experimental design. All planted containers were placed outdoors at the Vineland Research and Innovation Center (Vineland Station, $\mathrm{ON}$ ) on a black fabric-covered surface in a randomized block design, grouped by fertilization method. Ten replications of each fertilization method were arranged randomly within growing substrate groups, without space between pots. Plants within blocks were rerandomized monthly, and fertilization method blocks were rerandomized every 2 months to reduce location effect. Additional potted blueberry plants were placed around the perimeter of the plants to reduce perimeter effects. All plants were overwintered between 7 Jan. and 28 Apr. 2016 on a welldrained area in a covered outdoor structure at the Vineland Research and Innovation Center. Total monthly precipitation for the region and monthly mean minimum and maximum outdoor air temperatures are outlined in Table 1.

Measurements. Five plants per fertilization method were evaluated for plant growth, leaf chlorophyll content, growing substrate [intact in pot (i.e., root zone)] $\mathrm{pH}$ and $\mathrm{EC}$, nutrient deficiency symptoms, and overall appearance 1 week after transplanting (6 July 2015), biweekly thereafter until 30 Sept.

Table 1. Outdoor environmental conditions during potted blueberry production in the 2015 and 2016 growing seasons.

\begin{tabular}{|c|c|c|c|c|}
\hline \multirow[b]{2}{*}{ Month } & \multirow[b]{2}{*}{ Total monthly precipitation $(\mathrm{mm})^{z}$} & & \multicolumn{2}{|c|}{ Mean monthly air temp $\left({ }^{\circ} \mathrm{C}\right)^{\mathrm{z}}$} \\
\hline & & & Minimum & Maximum \\
\hline July & 20.7 & & 15.8 & 26.6 \\
\hline October & 75.4 & & 7.1 & 15.4 \\
\hline November & 28.6 & & 3.9 & 11.9 \\
\hline December & 42.8 & & 1.9 & 8.3 \\
\hline February & 69.2 & & -4.8 & 3.1 \\
\hline March & 81.8 & & -0.4 & 7.8 \\
\hline April & 26.1 & & 0.7 & 9.4 \\
\hline May & 15.5 & & 8.6 & 19.6 \\
\hline June & 19.2 & & 13.5 & 24.6 \\
\hline July & 48.1 & & 18.2 & 28.7 \\
\hline August & 41.1 & & 19.2 & 28.9 \\
\hline
\end{tabular}

${ }^{\mathrm{z}}$ Data obtained from Environment Canada (2016). 
2015, before dormancy (23 Oct. 2015), and for the duration of the 2016 growing season. Plant growth was evaluated by measuring plant height and width, in two perpendicular direc- tions, with the aboveground plant growth index calculated as [(Height $\times$ Width $_{1} \times$ Width $\left.\left._{2}\right) / 300\right]$, as outlined by Ruter (1992). Leaf chlorophyll content was measured using

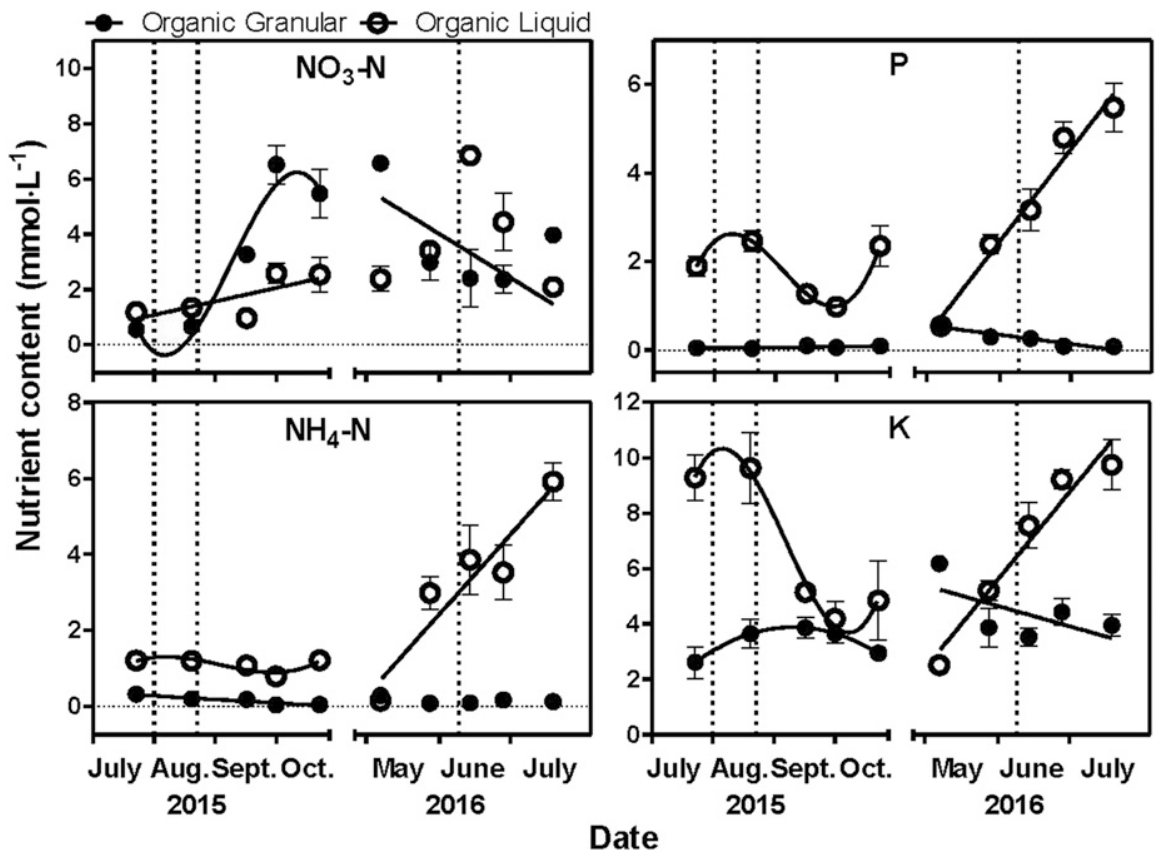

Fig. 1 Concentration of nitrate nitrogen $\left(\mathrm{NO}_{3}-\mathrm{N}\right)$, ammonium-nitrogen $\left(\mathrm{NH}_{4}-\mathrm{N}\right)$, phosphorus $(\mathrm{P})$, and potassium (K) during the 2015 and 2016 growing seasons in the root zone of $\# 5$ potted 'Duke' northern highbush blueberry plants fertilized with $10.2 \mathrm{~g} /$ pot N organic granular (OG; $1: 1.82$ general-purpose $4 \mathrm{~N}$ $1.3 \mathrm{P}-7.5 \mathrm{~K}$ :bloodmeal $12 \mathrm{~N}-0 \mathrm{P}-0 \mathrm{~K}$ ) or $18.6 \mathrm{mmol} \cdot \mathrm{L}^{-1}$ organic liquid $[(\mathrm{OL}) 1: 13.1$ general-purpose $2.5 \mathrm{~N}-$ $13.1 \mathrm{P}-4.2 \mathrm{~K}: 0 \mathrm{~N}-0 \mathrm{P}-0 \mathrm{~K}+6 \mathrm{CaO}$ (calcium oxide)] fertilizers. Values are means of three replications $\pm \mathrm{SE}$. When significance over time was observed $(P<0.05)$, lines indicate the calculated regression; otherwise, no lines are shown. Vertical dashed lines indicate the dates of OG top-dressed fertilizer application. a CCM-300 Chlorophyll Content Meter (OptiSciences, Inc., Hudson, NH). Growing substrate $\mathrm{pH}, \mathrm{EC}$, and nutrient content were measured for the growing substrate solution obtained using the pour-through method (Wright, 1986). Growing substrate nutrient content (i.e., $\mathrm{NO}_{3}-\mathrm{N}, \mathrm{NH}_{4}-\mathrm{N}, \mathrm{P}$, and $\mathrm{K}$ ) was determined for the OG 10.2-g/pot $\mathrm{N}$ and $\mathrm{OL}$ 18.6-mmol. $\mathrm{L}^{-1} \mathrm{~N}$ fertilization methods at five time points using a Varian Vista Pro inductively coupled plasma optical emission spectrometry with an axially viewed plasma (Varian Inc., Palo Alto, CA; SGS Agri-Food Laboratories). Visual nutrient disorder symptoms were noted, and overall appearance for five plants per fertilization method was ranked from 1 (worst) to 5 (best), relative to plants within the same fertilization method treatment. Overall appearance ranking values were based on foliage density and color, plant vigor, and extent of branching. Weeds were removed from containers as observed. During the second growing season, fresh fruit weight was measured two to three times weekly between 30 June and 8 Aug. 2016. After a total of 15 months of growth, leaves were removed from five representative plants for each of the $\mathrm{C}$, OG, and OL fertilization methods, and leaf area per plant was evaluated in early Aug. 2016 using a leaf area meter (LI-3100; LICOR, Lincoln, NE). Leaves and stems cut at the surface of the growing substrate were dried in paper bags in an oven at $70{ }^{\circ} \mathrm{C}$ until a constant weight was achieved to determine shoot dry weight per plant.

Statistical analysis. All data sets were analyzed using GraphPad Prism version
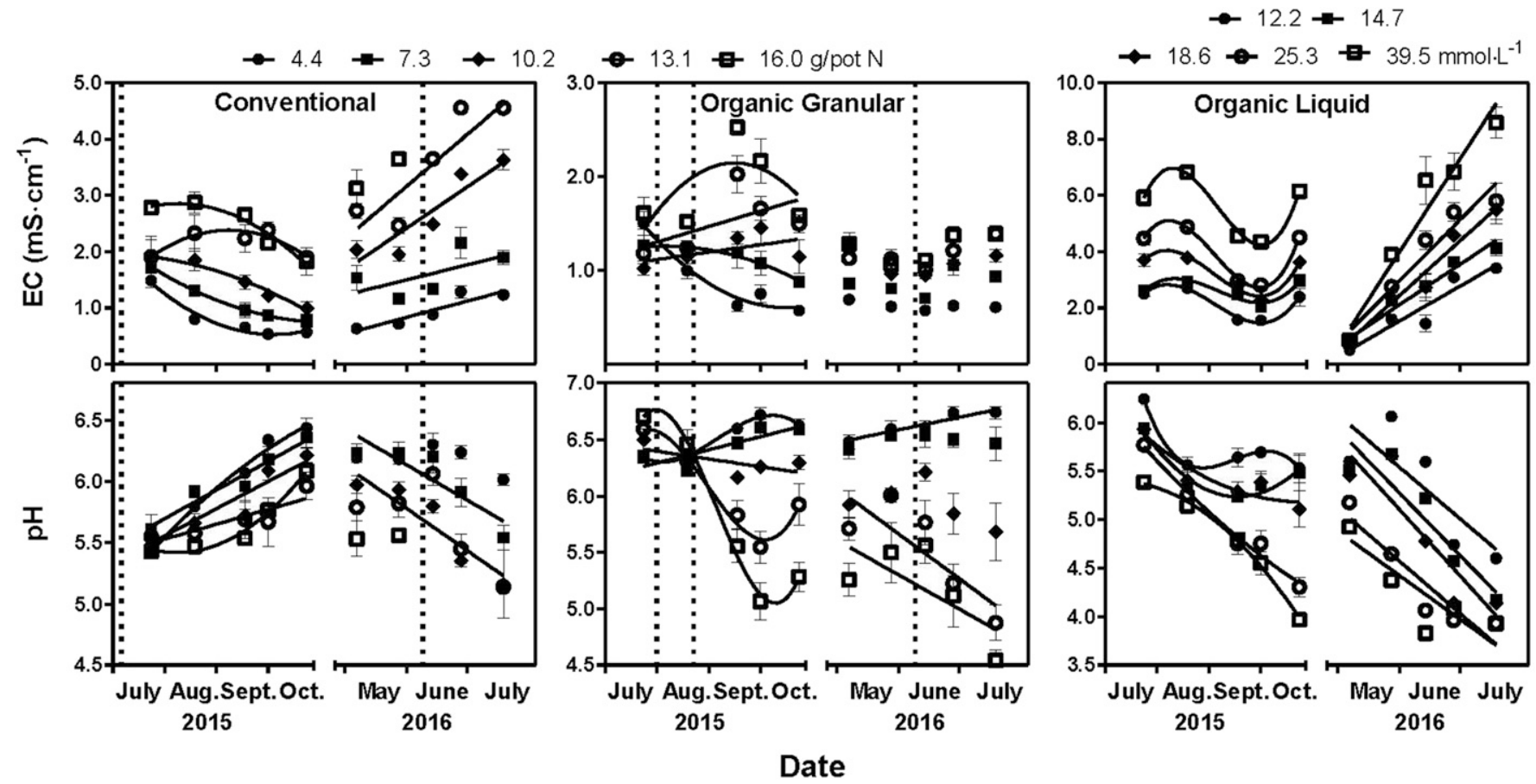

Fig. 2. Growing substrate electrical conductivity $(\mathrm{EC})$ and $\mathrm{pH}$ for $\# 5$ containerized 'Duke' northern highbush blueberry grown in conventional growing substrate with Osmocote Plus 15N-3.9P-9.9K 5- to 6-month controlled-release fertilizer or in organic growing substrate with granular (1:1.82 general-purpose 4N$1.3 \mathrm{P}-7.5 \mathrm{~K}$ :bloodmeal $12 \mathrm{~N}-0 \mathrm{P}-0 \mathrm{~K}$ ) or liquid $[1: 13.1$ general-purpose $2.5 \mathrm{~N}-13.1 \mathrm{P}-4.2 \mathrm{~K}: 0 \mathrm{~N}-0 \mathrm{P}-0 \mathrm{~K}+6 \mathrm{CaO}$ (calcium oxide)] organic fertilizers at five rates. Values are means of five replications $\pm \mathrm{SE}$. When significance over time was observed $(P<0.05)$, lines indicate the calculated regression; otherwise, no lines are shown. Vertical dashed lines indicate the dates of top-dressed fertilizer application. 

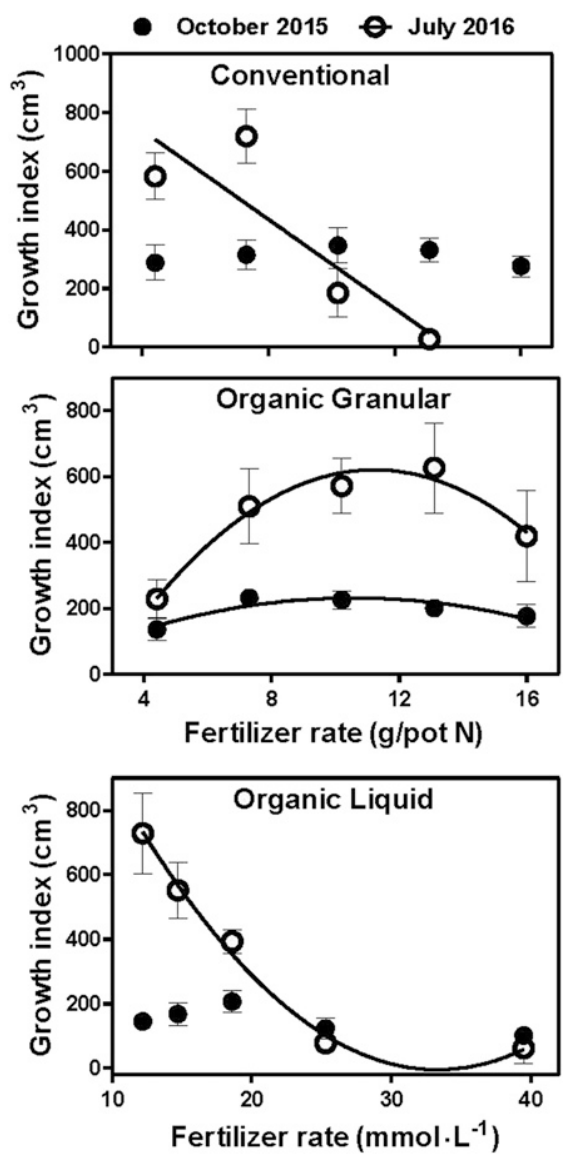

Fig. 3. Growth index on 23 Oct. 2015 and 18 July 2016 for \#5 containerized 'Duke' northern highbush blueberry grown in conventional growing substrate with Osmocote Plus 15N-3.9P-9.9K 5to 6-month controlled-release fertilizer or in organic growing substrate with granular (1:1.82 general-purpose $4 \mathrm{~N}-1.3 \mathrm{P}-7.5 \mathrm{~K}$ :blood meal $12 \mathrm{~N}-0 \mathrm{P}-0 \mathrm{~K})$ or liquid [1:13.1 general-purpose $2.5 \mathrm{~N}-13.1 \mathrm{P}-4.2 \mathrm{~K}: 0 \mathrm{~N}-0 \mathrm{P}-0 \mathrm{~K}+6 \mathrm{CaO}$ (calcium oxide)] organic fertilizers at five rates. Values are means of five replications $\pm \mathrm{SE}$. When significance over time was observed $(P<0.05)$, lines indicate the calculated regression; otherwise, no lines are shown. Symbol omission for the conventional fertilization method at $16.0 \mathrm{~g} /$ pot nitrogen on 18 July 2016 is a result of the lack of plant survival.

5.03 software (GraphPad Software Inc., La Jolla, CA). A two-way repeated-measures analysis of variance (ANOVA) with a Bonferroni posttest was used to evaluate differences for fertilizer rate and fertilization method combinations among time points for growth index, chlorophyll content, leaf color, overall appearance, and growing substrate $\mathrm{EC}$ and $\mathrm{pH}$. A one-way ANOVA was conducted for substrate nutrient content, total fruit yield, leaf area, and shoot dry weight among fertilization methods, with differences among means determined according to Tukey's multiple comparison test. Pearson correlation coefficients were calculated to compare substrate EC and $\mathrm{pH}$ with substrate nutrient content. Regression analyses were used to relate overall appearance, substrate nutrient content, EC and $\mathrm{pH}$ among time points, as well as leaf color and growth index among fertilization methods to estimate regression parameters for the best-fit regression model (linear, quadratic, or cubic). Using significant regression equations, the best ranges of fertilizer application rates for each fertilization method were calculated as the upper $90 \%$ range on the quadratic curve for growth index. All data were evaluated using a significance level of $P<0.05$.

\section{Results}

Growing substrate nutrient content, EC, and $p H$. Substrate $\mathrm{NO}_{3}-\mathrm{N}, \mathrm{NH}_{4}-\mathrm{N}$, and $\mathrm{P}$ contents increased over time from July to Oct. 2015 and decreased over time from May to July 2016 for OG at $10.2 \mathrm{~g} /$ pot N (Fig. 1). For OL at $18.6 \mathrm{mmol} \cdot \mathrm{L}^{-1} \mathrm{~N}$, substrate $\mathrm{K}, \mathrm{NH}_{4}-\mathrm{N}$, and $\mathrm{P}$ contents decreased over time from July to Oct. 2015, and increased over time from May to July 2016. In both 2015 and 2016, $\mathrm{NO}_{3}-\mathrm{N}$ had the most variability over time for the OG fertilization method. At the end of the 2015 growing season (i.e., 1 Oct. 2015) and as the study was finishing (i.e., 18 July 2016), growing substrate $\mathrm{NO}_{3}-\mathrm{N}$ content was less whereas $\mathrm{NH}_{4}-\mathrm{N}, \mathrm{P}$, and $\mathrm{K}$ values were greater for OL in 2016 than OG in 2015 and 2016. Growing substrate $\mathrm{EC}$ and $\mathrm{pH}$ correlated positively with $\mathrm{NH}_{4}-\mathrm{N}, \mathrm{P}$, and $\mathrm{K}(0.56,0.72$, and 0.78$)$ in 2015 , and with $\mathrm{NH}_{4}-\mathrm{N}$ and $\mathrm{P}(0.56$ and 0.70$)$ content in 2016 for $\mathrm{OL}$ at 18.6 $\mathrm{mmol} \cdot \mathrm{L}^{-1} \mathrm{~N}$. No correlations between OG at $10.2 \mathrm{~g} /$ pot $\mathrm{N}$ and growing substrate $\mathrm{EC}$ and $\mathrm{pH}$ were observed in 2015 or 2016

Growing substrate EC decreased in 2015 and increased in 2016 for all $\mathrm{C}$ fertilizer rates (Fig. 2). For OG, growing substrate EC decreased during 2015 at 4.4 and $7.3 \mathrm{~g} / \mathrm{pot}$ $\mathrm{N}$, but remained constant in 2016 at these rates. At 10.2, 13.1, and $16.0 \mathrm{~g} /$ pot $\mathrm{N}$, OG growing substrate EC increased or remained constant in both 2015 and 2016. A decreasing or constant growing substrate EC was observed for OL at all rates except 39.5 $\mathrm{mmol} \cdot \mathrm{L}^{-1} \mathrm{~N}$ in 2015 , whereas EC increased greatly at all OL rates in 2016 (Fig. 2).

During 2015, growing substrate $\mathrm{pH}$ increased for all $\mathrm{C}$ rates and for $\mathrm{OG}$ at lower rates (i.e., 4.4 and $7.3 \mathrm{~g} /$ pot $\mathrm{N}$ ), but tended to decrease for the remainder of OG and all OL rates (Fig. 2). Decreasing $\mathrm{pH}$ was observed in 2016 for all fertilizer types and rates except $\mathrm{OG}$ at $4.4 \mathrm{~g} /$ pot N.

Plant growth. At the end of the 2015 growing season and at the study completion in 2016, growth index showed a quadratic relationship with fertilizer rate for $O G$ (Fig. 3). Decreasing linear and quadratic relationships for growth index in response to $\mathrm{C}$ and $\mathrm{OL}$ fertilizer rates, respectively, were observed at the study completion in 2016, with no surviving plants remaining for $\mathrm{C}$ at $16.0 \mathrm{~g} /$ pot N. At the end of the study in Aug. 2016, leaf area and total shoot dry weight were greatest for $\mathrm{C}$ at 4.4 and 7.3 $\mathrm{g} /$ pot N, OG at $10.2 \mathrm{~g} /$ pot N, and OL at 12.2 and $14.7 \mathrm{mmol} \cdot \mathrm{L}^{-1} \mathrm{~N}$ (data not shown).

Chlorophyll content and visual leaf color observations. Chlorophyll content of leaves in the lower portion of the plant canopy was greater than chlorophyll content of the last fully expanded leaves in the upper portion of the plant canopy for C, OG, and OL treatments at all fertilizer rates at the end of the 2015 growing season and at the study completion in 2016 (Fig. 4). In general, the greatest chlorophyll content was observed at midrange fertilizer rates in 2015 and low fertilizer rates in 2016.

Visual observations of leaf color for the $\mathrm{C}$ fertilizer method detected interveinal chlorosis for more plants at $16.0 \mathrm{~g} /$ pot $\mathrm{N}$ than 4.4 and 7.3 $\mathrm{g} /$ pot $\mathrm{N}$ at the majority of time points in 2015 . No significant difference for $\mathrm{C}$ leaf color among fertilizer rates was observed for the majority of time points in 2016. For OG, interveinal chlorosis decreased over time for 4.4 and $7.3 \mathrm{~g} /$ pot $\mathrm{N}$ in 2015 , and increased over time for all but $4.4 \mathrm{~g} /$ pot $\mathrm{N}$ in 2016 . Interveinal chlorosis for OL decreased over time for all rates in 2015 and did not change significantly over time in 2016 for the majority of rates.

Overall appearance. Plants with the greatest overall appearance had large plant sizes, consistent foliage density, a compact shape and no interveinal chlorosis. Mean overall appearance rankings per fertilization method among biweekly evaluations in 2015 increased linearly over time for $\mathrm{C}$ at 4.4 and $7.3 \mathrm{~kg} \cdot \mathrm{m}^{-3} \mathrm{~N}, \mathrm{OG}$ at $7.3 \mathrm{~kg} \cdot \mathrm{m}^{-3} \mathrm{~N}$, and $\mathrm{OL}$ at $14.7 \mathrm{mmol} \cdot \mathrm{L}^{-1} \mathrm{~N}$ (data not shown). The greatest fertilizer application rate for $\mathrm{C}$, OG (i.e., $16.0 \mathrm{~g} /$ pot $\mathrm{N}$ ), and $\mathrm{OL}$ (i.e., $39.5 \mathrm{mmol} \cdot \mathrm{L}^{-1} \mathrm{~N}$ ) resulted in a linear decline in overall appearance ranking with time during the 2015 growing season. Overall appearance for $\mathrm{OL}$ at $39.5 \mathrm{mmol} \cdot \mathrm{L}^{-1} \mathrm{~N}$ was less than all other OL application rates except $25.3 \mathrm{mmol} \cdot \mathrm{L}^{-1} \mathrm{~N}$ at the end of the 2015 growing season (23 Oct. 2015). At the end of the study in 2016, the greatest overall appearance was observed for $\mathrm{C}$ at 4.4 and $7.3 \mathrm{~g} /$ pot N, and OL at 12.2, 14.7, and $18.6 \mathrm{mmol} \cdot \mathrm{L}^{-1} \mathrm{~N}$. No difference in overall appearance occurred among OG rates at the end of the study in 2016.

Blueberry fruit yield. In 2015, no fruit was produced by plants in any growing substrate. In 2016, a large total fruit fresh weight (i.e., 243.2-344.5 g/plant) (Fig. 5) was produced by OG plants at all fertilizer rates, with no significant difference among rates. For $\mathrm{C}$ plants, fertilization at rates of 4.4, 7.3, and $10.2 \mathrm{~g} /$ pot $\mathrm{N}$ produced the greatest total fresh weight of fruit, whereas OL plants produced the greatest fresh weight at 12.2, 14.7, and $18.6 \mathrm{mmol} \cdot \mathrm{L}^{-1} \mathrm{~N}$. Surviving plants in all fertilization methods set fruit, with the lowest yields produced by the greatest $\mathrm{C}$ (i.e., $10.9 \mathrm{~g}$ for $13.1 \mathrm{~g} / \operatorname{pot} \mathrm{N}$ ) and OL (i.e., $15.0 \mathrm{~g}$ for 39.5 $\mathrm{mmol} \cdot \mathrm{L}^{-1} \mathrm{~N}$ ) fertilizer rates.

\section{Discussion}

A desirable fertilization method should provide plants with adequate amounts of available nutrients, without excess nutrient leaching to the environment. The current study investigated the efficacy of different fertilization methods (i.e., different fertilizer types and application methods) for use in potted blueberry production. Analysis of pour-through solution from midrange fertilizer rates for 

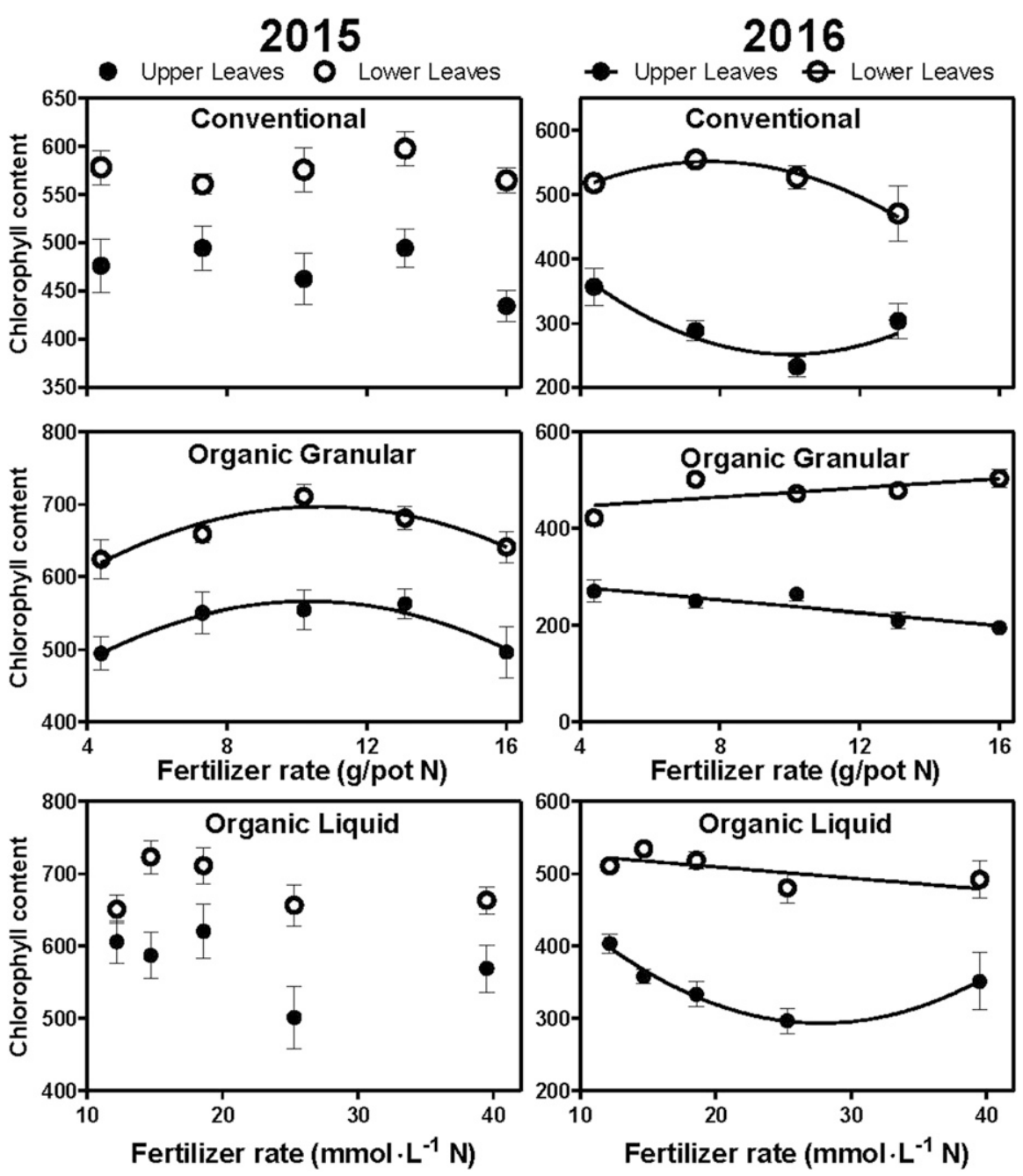

Fig. 4. Chlorophyll content on 23 Oct. 2015 and 19 July 2016 for leaves of \#5 containerized 'Duke' northern highbush blueberry plants grown in conventional growing substrate with Osmocote Plus $15 \mathrm{~N}-3.9 \mathrm{P}-9.9 \mathrm{~K}, 5$ - to 6-month controlled-release fertilizer or in organic growing substrate with granular $(1: 1.82$ general-purpose $4 \mathrm{~N}-1.3 \mathrm{P}-7.5 \mathrm{~K}$ :bloodmeal $12 \mathrm{~N}-0 \mathrm{P}-0 \mathrm{~K})$ or liquid $[1: 13.1$ generalpurpose $2.5 \mathrm{~N}-13.1 \mathrm{P}-4.2 \mathrm{~K}: 0 \mathrm{~N}-0 \mathrm{P}-0 \mathrm{~K}+6 \mathrm{CaO}$ (calcium oxide)] organic fertilizers at five rates. Values are means \pm SE. When significance over time was observed $(P<0.05)$, lines indicate the calculated regression; otherwise, no lines are shown. Symbol omission for the conventional fertilization method at $16.0 \mathrm{~g} /$ pot $\mathrm{N}$ on 19 July 2016 is a result of the lack of plant survival.

OG and OL showed that nutrient content in the growing substrate varied greatly over time. In particular, for $\mathrm{OG}, \mathrm{NO}_{3}-\mathrm{N}$ showed the greatest variability of any nutrient for this fertilization method, whereas $\mathrm{NH}_{4}-\mathrm{N}$ was continually observed at low levels. For $\mathrm{OL}, \mathrm{NO}_{3}-\mathrm{N}$ increased over time in 2015, whereas $\mathrm{NH}_{4}-\mathrm{N}$ increased over time in 2016. The different nutrient content patterns observed for these two $\mathrm{N}$ sources over time were likely a result of both the initial composition of $\mathrm{N}$ sources in the fertilizers, as well as preferential uptake of $\mathrm{NH}_{4}$ - rather than $\mathrm{NH}_{3}$-type $\mathrm{N}$ by blueberry roots (Bryla et al., 2010; Strik, 2016). The decrease in $\mathrm{NH}_{4}-\mathrm{N}, \mathrm{P}$, and $\mathrm{K}$ over time with OL in 2015 likely indicates plant uptake or leaching of these nutrients during a period of active plant growth and adequate soil moisture. However, increasing $\mathrm{NH}_{4}-\mathrm{N}, \mathrm{P}$, and $\mathrm{K}$ nutrient levels over time in 2016 suggests excess nutrient availability compared with plant requirements during this time. For OG, the low levels of $\mathrm{P}$ and $\mathrm{K}$ throughout the study likely reflected nutrient availability matching plant uptake or low levels of nutrient release resulting from characteristics of the fertilizer components (i.e., sulfate of potash, guano soft rock phosphate, rock phosphate, feather meal, sulfate of potash-magnesia, soybean meal, and humic acid derivatives).

Blueberry plants grown with high fertilizer rates for all fertilizer methods in 2015 showed low growth index, poor overall appearance, and interveinal chlorosis, likely a result of high EC levels (i.e., $>3.0 \mathrm{mS} \cdot \mathrm{cm}^{-1}$ ). Irrigation water did not contribute to the observed high EC, because irrigation water EC $\left(0.2 \mathrm{mS} \cdot \mathrm{cm}^{-1}\right)$ and bicarbonate alkalinity $\left(0.1 \mathrm{mg} \cdot \mathrm{L}^{-1}\right)$ were less than recommended maximums for blueberries [i.e., $0.25 \mathrm{mS} \cdot \mathrm{cm}^{-1}$ and $91.5 \mathrm{mg} \cdot \mathrm{L}^{-1}$ (Puls, 1999)]. Because blueberry roots have a very fine texture (Valenzuela-Estrada et al., 2008), overapplication of fertilizer, resulting in high EC levels, poses a great risk of root damage and poor blueberry plant health (Bryla and Machado,
2011). For the $O G$ and $C$ treatments at the majority of fertilizer rates, and for the OL treatment at 12.2 and $14.7 \mathrm{mmol} \cdot \mathrm{L}^{-1} \mathrm{~N}, \mathrm{EC}$ was maintained at levels less than $3.0 \mathrm{mS} \cdot \mathrm{cm}^{-1}$ during the 2015 growing season. Interestingly, growing substrate EC during Sept. 2015 for OL and OG at high fertilizer rates was at the lowest and highest levels, respectively, since the beginning of the study. The low OL growing substrate EC at high fertilizer rates in Sept. 2015 likely occurred because plants were large enough to take up nutrients (e.g., $\mathrm{NH}_{4}-\mathrm{N}, \mathrm{P}, \mathrm{K}$ ) at sufficient levels to lower the growing substrate EC, whereas high EC for OG at high fertilizer rates suggest plants had excess nutrients available in the substrate at that time. During the 2016 growing season, growing substrate EC levels increased or remained constant, which was likely the cause of desirable plant growth and fruit yield. Growing substrate $\mathrm{pH}$ levels decreased during 2016 for the majority of fertilizer rates, likely the result of acidified water for OG and OL as well as the influences of fertilizer, because high $\mathrm{NH}_{4}-\mathrm{N}$ fertilizer can lower growing substrate $\mathrm{pH}$ via plant uptake and nitrification.

Understanding the adequate amount of nutrients required by blueberry plants at different stages of growth is critical to developing nutrient management strategies for successful potted blueberry plant production. In addition, ensuring adequate nutrient availability by maintaining appropriate root-zone $\mathrm{pH}$ levels will encourage healthy plant growth. In our study, OG and OL substrates had an initial $\mathrm{pH}$ greater than the range appropriate for blueberry growth [i.e., 4.25.5 (Puls, 1999)] at all fertilizer rates. Although the $\mathrm{pH}$ decreased for some OG and OL fertilizer rates, the majority of $\mathrm{OG}$ and OL remained greater than 5.5 during the 2015 growing season, as did OG for low fertilizer rates in 2016, despite acidification of high-pH (6.91) irrigation water. Also, the $\mathrm{pH}$ of $\mathrm{C}$ increased and remained greater than 5.5 during the 2015 and 2016 growing seasons. Irrigation water during 2015 had an average $\mathrm{pH}$ of 6.91 , which was not acidified with apple cider vinegar for the $\mathrm{C}$ fertilization method and therefore likely influenced the high $\mathrm{pH}$ of the growing substrate for $\mathrm{C}$. In addition to low iron availability at high $\mathrm{pH}$ levels, blueberry plants are inefficient at taking up iron at $\mathrm{pH}$ levels more than 5.5 (Strik, 2016). Therefore, the combination of high growing substrate $\mathrm{pH}$ and EC levels likely combined to cause the observed interveinal chlorosis symptoms.

Fruit yield was influenced by fertilizer rate, with high $\mathrm{C}$ rates and all $\mathrm{OL}$ rates affecting fruit yield negatively. The high fruit yield observed for all OG rates and $\mathrm{C}$ at 4.4 and $7.3 \mathrm{~g} /$ pot $\mathrm{N}$ indicated that blueberry plants prefer low $\mathrm{C}$ rates, or $\mathrm{OG}$ fertilizer applied at any rate. When using conventional CRFs, low rates (i.e., 4.4-7.3 g/pot $\mathrm{N}$ ) are sufficient for high fruit yield in this production system, and no yield benefit was observed from high application rates. When using the OG fertilization method, fruit production responded positively at all application rates; therefore, lower OG fertilizer rates are appropriate and cost-effective. Of the three fertilizer methods, 


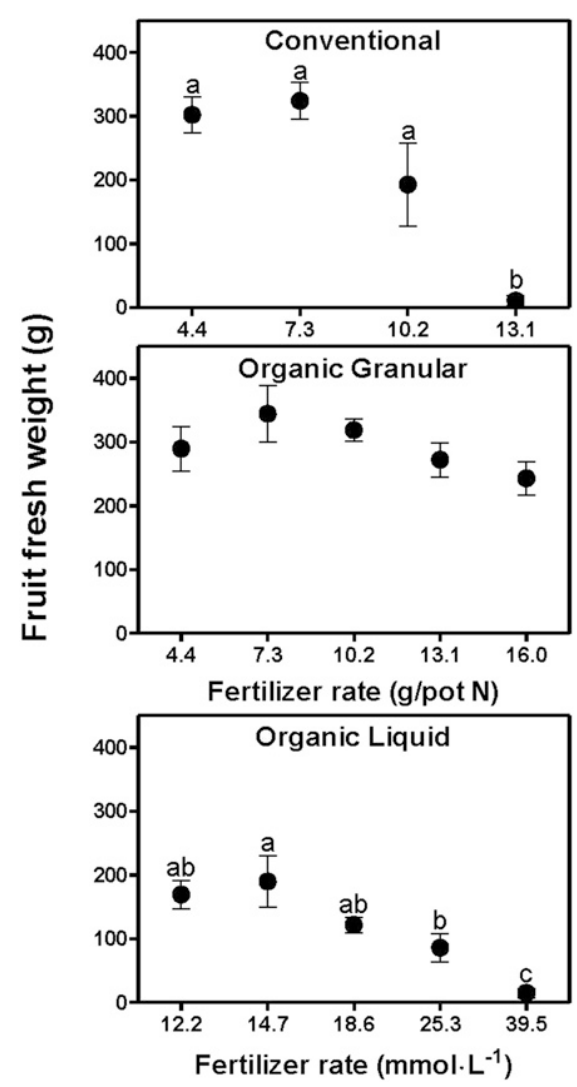

Fig. 5. Total fruit fresh weight at the end of the 2016 growing season for \#5 containerized 'Duke' northern highbush blueberry plants grown in conventional growing substrate with Osmocote Plus 15N-3.9P-9.9K, 5- to 6-month controlled-release fertilizer or in organic growing substrate with granular (1:1.82 generalpurpose $4 \mathrm{~N}-1.3 \mathrm{P}-7.5 \mathrm{~K}$ :bloodmeal $12 \mathrm{~N}-0 \mathrm{P}-0 \mathrm{~K})$ or liquid [1:13.1 general-purpose $2.5 \mathrm{~N}-13.1 \mathrm{P}-$ $4.2 \mathrm{~K}: 0 \mathrm{~N}-0 \mathrm{P}-0 \mathrm{~K}+6 \mathrm{CaO}$ (calcium oxide)] organic fertilizers. Values are means of five replications \pm SE. When differences among treatments per fertilization method were observed, symbols bearing the same letter are not significantly different at $P<0.05$.

OL is least suitable for high blueberry fruit yield using this production system.

For the blueberry plants in our study, fertilizer rate greatly influenced growth index. Specifically, overfertilization at high OG, OL, and $\mathrm{C}$ application rates in 2016 influenced growth index negatively, similar to the overfertilization observations by Wilber and Williamson (2008). The organic fertilizers may have accumulated within the growing substrate over time in 2016; therefore, applying organic fertilizers based on measured EC levels of the growing substrate is recommended. Based on growth index values, 8.50 to $13.95 \mathrm{~g} /$ pot $\mathrm{N}$ was calculated as the best range for plant growth with the OG fertilization method, whereas 4.4 and $7.3 \mathrm{~g} /$ pot $\mathrm{N}$ for $\mathrm{C}$ or 12.2 and $14.7 \mathrm{mmol} \cdot \mathrm{L}^{-1} \mathrm{~N}$ for $\mathrm{OL}$ would be most appropriate to encourage the best blueberry plant growth. In addition to preventing nutrient toxicity symptoms, and nutrient leaching, applying fertilizer at these $\mathrm{C}$ and OL rates and this OG range may be most cost effective for growers to encourage healthy blueberry plant growth using this type of production system.
No single fertilizer rate resulted in the greatest overall appearance for the duration of the study for any fertilization method, potentially because of nutrient needs changing over time or the result of effects from changes in $\mathrm{EC}$ or $\mathrm{pH}$ over time. Further study is needed to determine whether either optimal and consistent $\mathrm{EC}$ and $\mathrm{pH}$ levels, or time-adjusted EC and $\mathrm{pH}$ levels based on plant need, would be able to provide insight into ensuring a consistent, desirable overall appearance for blueberry plants in these growing systems.

Timing and method of fertilizer application allows growers to influence the nutrient status of the root zone (Bryla et al., 2010). Applying a liquid fertilizer is beneficial because it permits the grower to adjust fertilizer timing and concentration to suit the needs of the crop more effectively, whereas granular and CRF fertilizer types are less labor-intensive than liquid fertilization but offer a limited ability to change fertilization practices quickly in response to crop need. In our study, preparation and application of the liquid fertilizer resulted in an oily film on surfaces as well as rapid settling of particles in the organic fertilizer solution. As a result of these observations, the OL fertilizer used in our study may not be appropriate for use with some irrigation systems or nozzles because of the potential of the fertilizer to clog the lines or leave an oily residue. Because the OL fertilizer was applied directly to the surface of the growing substrate, the influence of this fertilizer on plant leaves was not observed.

Physical and chemical properties of the growing substrate play an important role in maintaining appropriate $\mathrm{EC}$ and $\mathrm{pH}$ levels in the root zone. In our study, no negative effects on blueberry plant growth were caused by the substrates; therefore, both substrates are suitable for potted blueberry production in both a nursery and home garden context.

Overall, with the goal of efficient plant growth in the nursery or high fruit yield for container blueberry production by home gardeners, this study found that high fertilizer application rates are not necessary, and can be detrimental to plant growth and fruit production. Considering blueberry plant growth index, shoot dry weight, leaf area, overall appearance, and fruit yield, the results suggest optimal fertilizer application ranges from 4.4 to 7.3 $\mathrm{g} /$ pot $\mathrm{N}$ for $\mathrm{C}$ treatments, from 12.2 to 14.7 $\mathrm{mmol} \cdot \mathrm{L}^{-1} \mathrm{~N}$ for OL treatments, and from 8.50 to $13.95 \mathrm{~g} /$ pot $\mathrm{N}$ for OG treatments. With target $\mathrm{EC}$ and $\mathrm{pH}$ levels in mind, organic and conventional container blueberry growers can supply appropriate nutrient levels at the correct time to manage substrate fertility, while achieving healthy plant growth and high fruit yields.

\section{Literature Cited}

Agriculture and Agri-Food Canada. 2003. Canadian nursery crop profile: Container production. 23 Sept. 2019. <http://publications.gc.ca/collections/ collection_2009/agr/A118-10-27-2003E.pdf>.

Brazelton, C. 2011. World blueberry acreage \& production. 7 Aug. 2015. <http://www.oregonblueberry. com/update/USHBC-report.pdf $>$.

Bryla, D.R. and R.M.A. Machado. 2011. Comparative effects of nitrogen fertigation and granular fertilizer application on growth and availability of soil nitrogen during establishment of highbush blueberry. Front. Plant Sci. 2:1-8.

Bryla, D.R., A.D. Shireman, and R.M.A. Machado. 2010. Effects of method and level of nitrogen fertilizer application on soil $\mathrm{pH}$, electrical conductivity, and availability of ammonium and nitrate in blueberry. Acta Hort. 868:95-101.

de Silva, A., K. Patterson, C. Rothrock, and R. McNew. 1999. Phytophthora root rot of blueberry increases with frequency of flooding. HortScience 34:693-695.

Environment Canada. 2016. Climate: Daily data (2015). 17 Feb. 2016. <http://climate.weather.gc.ca/ climateData/dailydata_e.html?timeframe $=2 \&$ Prov $=$ ON\&StationID $=31367 \&$ dlyRange $=$ 2002-02-07\%7C2016-02-15\&Year=2015\& Month $=7 \& \mathrm{cmdB} 1=$ Go\&Day $=1>$.

Fonteno, W.C. and C.T. Harden. 2014. Procedures for determining physical properties of horticultural substrates using the NCSU Porometer 20 Feb. 2016. <https://projects.ncsu.edu/project/ hortsublab/pdf/porometer_manual.pdf $>$.

Heiberg, N. and R. Lunde. 2006. Effect of growth media on highbush blueberries grown in pots. Acta Hort. 715:219-223.

Hortidaily. 2015. Developments in substrates for the soft fruit sector. 21 July $2015 .<\mathrm{http} / / /$ www.hortidaily.com/article/19284/Developmentsin-substrates-for-the-soft-fruit-sector>.

Kingston, P.H., C.F. Scagel, D.R. Bryla, and B. Strik. 2017. Suitability of sphagnum moss, coir, and douglas fir bark as soilless substrates for container production of highbush blueberry. HortScience 52:1692-1699.

Machado, R.M.A., D.R. Bryla, and O. Vargas. 2014. Effects of salinity induced by ammonium sulfate fertilizer on root and shoot growth of highbush blueberry. Acta Hort. 1017:407-414.

Miller, S.A., N. Patel, A. Muller, D.M. Edwards, and S.T. Solomona. 2006. A comparison of organic and conventional nutrient management protocols for young blueberry nursery stock. Acta Hort. 715:427-432.

Puls, E.E., Jr. 1999. Commercial blueberry production. 7 Aug. 2015. <https://www.lsuagcenter.com/ NR/rdonlyres/BBA23B58-BC7F-477A-9151BCE126AF2E7D/68621/pub2363blueberry2.pdf \$.

Retamales, J.B. and J.F. Hancock. 2012. Blueberries. 2nd ed. Crop Production Science in Horticulture series. CABI International, Wallingford, UK.

Ruter, J.M. 1992. Influence of source, rate, and method of applicating [sic] controlled release fertilizer on nutrient release and growth of 'Savannah' holly. Fert. Res. 32:101-106.

Smolarz, K. 1985. Growth of potted highbush blueberry plants as affected by medium and nitrogen nutrition. Acta Hort. 165:237-240.

Strik, B. 2016. Blueberry nutrient management. 23 Feb. 2016. <http://extension.missouri.edu/blueberry/ documents/Shared_Documents/MOBBSchool/ MOBBSchoolConf 1 1/Nutrition\%20of\%20Blueberry $\% 2010-7-11 \% 20 \mathrm{MO} \% 20$ Strik.pdf $>$.

Strik, B., A.J. Vance, and C.E. Finn. 2017. Northern highbush blueberry cultivars differed in yield and fruit quality in two organic production systems from planting to maturity. HortScience 56:844-851.

Valenzuela-Estrada, L.R., V. Vera-Caraballo, L.E. Ruth, and D.M. Eissenstat. 2008. Root anatomy, morphology, and longevity among root orders in Vaccinium corymbosum (Ericaceae). Amer. J. Bot. 95:1506-1514.

Wilber, W.L. and J.G. Williamson. 2008. Effects of fertilizer rate on growth and fruiting of containerized southern highbush blueberry. HortScience 43:143-145.

Wright, R.D. 1986. The pour through nutrient extraction procedure. HortScience 21:227-229. 